\title{
Bcl-2 Overexpression Prevents Motoneuron Cell Body Loss but Not Axonal Degeneration in a Mouse Model of a Neurodegenerative Disease
}

\author{
Y. Sagot, ${ }^{1}$ M. Dubois-Dauphin,, ${ }^{2}$ S. A. Tan, ${ }^{3}$ F. de Bilbao, ${ }^{2}$ P. Aebischer, ${ }^{3}$ J.-C. Martinou, ${ }^{4}$ and A. C. Kato ${ }^{1}$ \\ ${ }^{1}$ Department of Pharmacology and Division of Clinical Neuromuscular Research, and 2Department of Physiology, \\ Centre Médical Universitaire, Geneva, Switzerland, ${ }^{3}$ Gene Therapy Center and Surgical Research Division, \\ Lausanne University Medical School, Lausanne, Switzerland, and ${ }^{4}$ Glaxo Institute for Molecular Biology, Geneva, \\ Switzerland
}

Bcl-2 and its analogs protect different classes of neurons from apoptosis in several experimental situations. These proteins may therefore provide a means for treatment of neurodegenerative diseases. We examined the effects of $\mathrm{Bcl}-2$ overexpression in a genetic mouse model with motor neuron disease (progressive motor neuronopathy/pmn). $P m n / p m n$ mice lose motoneurons and myelinated axons, and die at 6 weeks of age. When these mice were crossed with transgenic mice that overexpress human $\mathrm{Bcl}-2$, there was a rescue of the facial motoneurons with a concomitant restoration of their normal soma size and expression of choline acetyltransferase. However, Bcl-2 overexpression did not prevent degeneration of myelinated axons in the facial and phrenic motor nerves and it did not increase the life span of the animals. Since Bcl-2 acts strictly on neuronal cell body survival without compensating for nerve degeneration in $\mathrm{pmn} / \mathrm{pmn} / \mathrm{bcl}-2$ mice, this proto-oncogene would not in itself be sufficient for treatment of neurodegenerative diseases where axonal impairment is a major component.

[Key words: pmn/pmn mice, progressive motor neuronopathy, Bcl-2, animal model of motor neuron disease, treatment of neurodegenerative disease, axonal degeneration]

Cell death is a major event in the developing nervous system and in certain pathological states such as ischemia and neurodegenerative diseases. The idea that the activation of a set of selected genes is responsible for neuronal cell death has been provided by the studies in C. elegans (Ellis et al., 1991). These observations have been extended to vertebrates where it has been shown that the proto-oncogene, $b c l-2$, can act as a natural repressor of apoptosis in the nervous system. In vitro, Bcl-2 has been reported to protect various neuronal cell types from apoptosis induced by deprivation of neurotrophic factors (Garcia et

\footnotetext{
Received June 27, 1995; revised July 26, 1995; accepted July 31, 1995.

We thank Dr. C. Henderson for reading the manuscript and N. Flores, V. Padrun, and L. Schnell for their excellent technical assistance. We would also like to thank Dr. J. Jacquet for his help with the statistical analysis. We are grateful to Dr. R. Vejsada for his valuable discussion, reading the manuscript, and assistance throughout the experiments. This work was supported by the Association Française contre les Myopathies (France), CytoTherapeutics Inc. (USA), and the Swiss National Science Foundation.

Correspondence should be addressed to Dr. Yves Sagot, Department of Pharamacologie, Centre Médical Universitaire, 1 Avenue Champel, 1211 Gencva 4, Switzerland.

Copyright $@ 1995$ Society for Neuroscience $0270-6474 / 95 / 157727-07 \$ 05.00 / 0$
}

al., 1992; Allsopp et al., 1993). By means of overexpression of $\mathrm{Bcl}-2$ in transgenic mice, it has been shown that this oncoprotein can protect neurons from naturally occuring cell death and from experimental ischemia (Martinou et al., 1994). Furthermore, Dubois-Dauphin et al. (1994) demonstrated that in transgenic neonatal mice that overexpress Bcl-2, facial motoneurons could be protected against axotomy-induced cell death. Even though the mechanism of action of Bcl-2 has not yet been elucidated, these results designate $\mathrm{Bcl}-2$ as a possible target for treatment in neurodegenerative diseases (Thompson, 1995).

To determine whether the protein Bcl-2 could prevent the disease progression in an animal model which mimics a human motor ncuron disease, we have crossed human Bcl-2 overexpressing miçe (Dubois-Dauphin et al., 1994) with $\mathrm{pmn} / \mathrm{pmn}$ mice, a genetic mouse model with neuromuscular dysfunction, called pmn because of its progressive motoneuronopathy. The pmn homozygotes develop weakness in the hind limbs during the third week of life and die at approximately 6 weeks of age (Schmalbruch et al., 1991). At this time, the animals show a severe muscle wasting particularly those of the thoracic and pelvic regions. Histological studies revealed that the sciatic and phrenic nerves are severely affected (Schmalbruch et al., 1991), and $30 \%$ of facial nucleus motoneurons degenerate (Sendtner et al., 1992).

In the present article, we describe the disease progression in pmn homozygotes which overexpress the human $b c l-2$ oncoprotein. Several aspects of the disease evolution (age of onset, lifespan and histological analyses of facial nucleus motoneurons and facial and phrenic nerves) were studicd.

\section{Materials and Methods \\ Production of pmn homozygote mice which overexpress the proto-oncogene bcl-2 \\ Pnn carrier mice were obtained from the laboratory of Dr. J. L. Guenet (Institut Pasteur, Paris); the litters (usually six to eight animals) contain statistically $25 \% \mathrm{pmn} / \mathrm{pmn}$ homozygotes. \\ A transgenic Bcl-2 overexpressing mouse from the line 71 (Dubois- Dauphin et al., 1994; Martinou et al., 1994) was crossed with $\mathrm{pmn} /+$ females in order to generate $p m n /+/ b c l 2 /+$ progeny $(\mathrm{F} 1$, selected by PCR analysis). Heterozygotes carrying the pmn mutation and the $b c l-2$ transgene were apparently normal. They were back-crossed with pmn' + breeders. The $\mathrm{F} 2$ generation contained the same proportions of $\mathrm{pmn} /$ pmn mutants and $p m n / p m n / b c l-2(28 / 199$ vs $26 / 199)$.}

\section{Histological procedures}

Facial nucleus. Mice were perfused at day 38 and processed for histological analysis as previously described (Sagot et al., 1995). The entire 

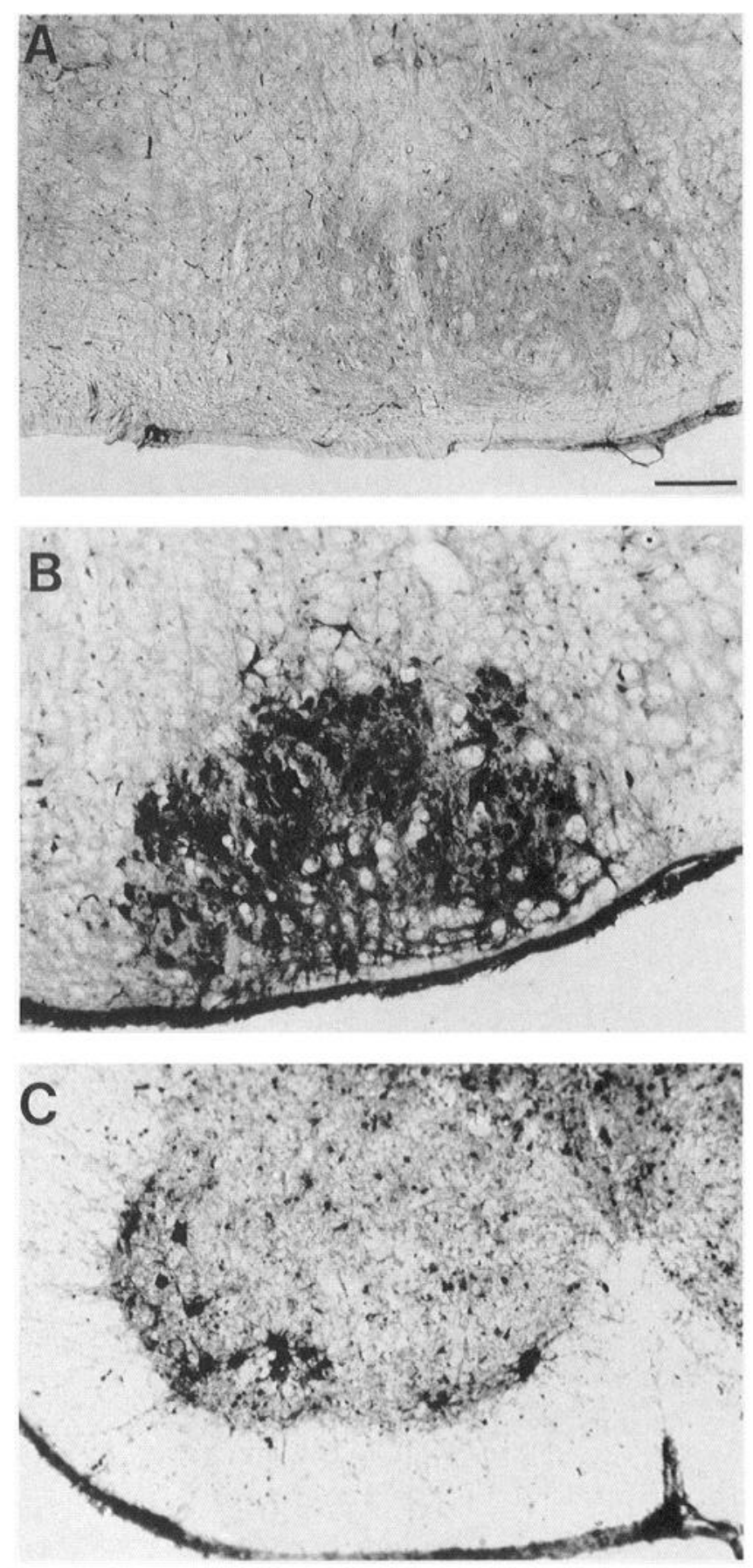

Figure 1. Immunohistochemical localization of human Bcl-2 antigen in $p m n / p m n ~(A)$ and $p m n / p m n / b c l-2$ mice $(B, C)$. A, No Bcl-2 labeling was found in the facial nucleus of non-Bcl2 overexpressing $\mathrm{pmn} / \mathrm{pmn}$ mice. In contrast, a very strong labeling of facial motoneurons $(B)$ or spinal motoneurons $(C)$ was found in $\mathrm{pmn} / \mathrm{pmn} / \mathrm{bcl}$-2 mice which overexpressed human $\mathrm{Bcl}-2$ oncoprotein. No labeling was obtained when the primary antibody was omitted. Scale bar, $150 \mu \mathrm{m}$.

Figure 2. a, Axotomy-induced cell death in control and in pmn/pmnbcl-2 strain. Facial motoneurons have been counted 3 weeks after lesion
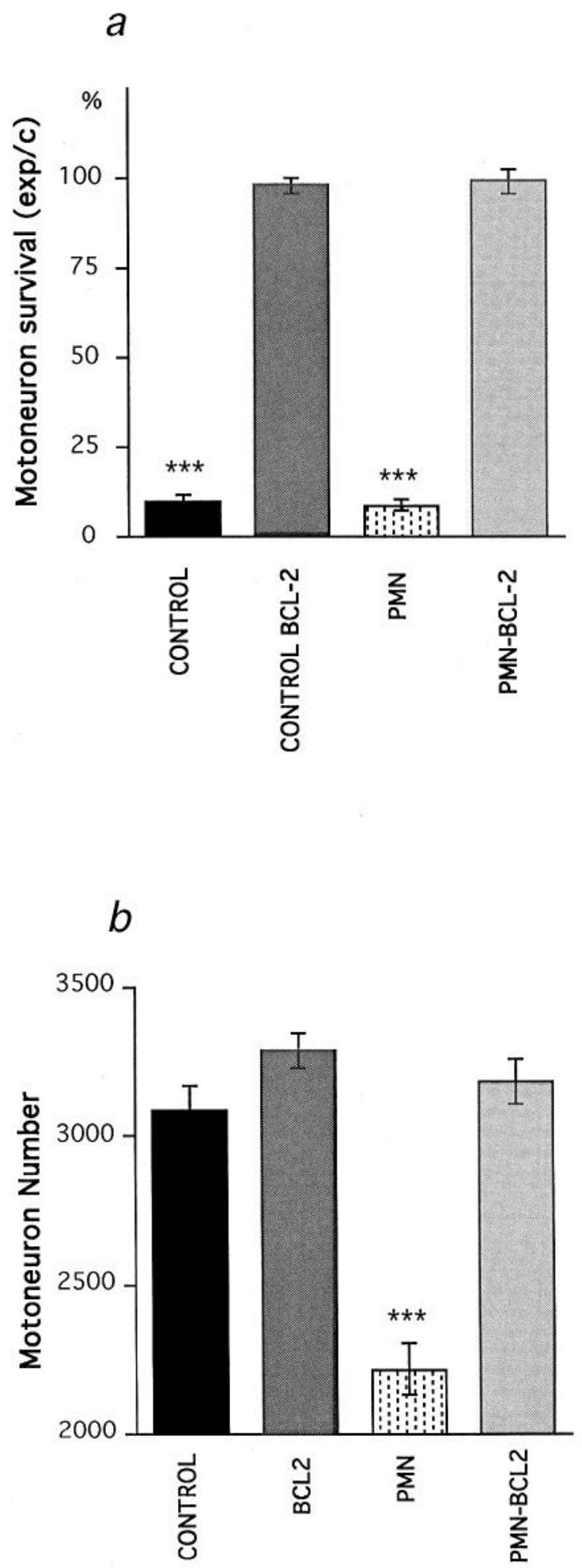

on both operated $(\exp )$ and the nonoperated $(c)$ side. Results are expressed as a percentage of cell counts on the lesioned side versus cell counts on the unlesioned side $(\exp / c)$. In control mice $(n=4)$ as well as in pmn mice $(n=3)$, Bcl-2 overexpression protects motoneurons from axotomy-induced cell death. In contrast, in controls $(n=3)$ or pmn $(n=3)$ mice which did not overexpress Bcl-2, axotomy caused severe cell loss $(* * *, p<0.001) . b, \mathrm{Bcl}-2$ rescues facial motoneurons in pmn/pmn/bcl-2 mice. Control $(n=3)$ and Bcl-2 control mice $(n=$ 4) did not show more motoneurons than $\mathrm{pmn} / \mathrm{pmn} / \mathrm{bcl}-2$ that overexpress Bcl-2 $(n=8)$. In contrast, the number of facial motoneurons is significantly $(* * *, p<0.001)$ reduced in $p m n / p m n$ mice $(n=6)$ as compared to the $\mathrm{pmn} / \mathrm{pmn} / \mathrm{bcl}-2$ or control animals. 


\begin{tabular}{|c|c|c|c|}
\hline Fxperimental animal & Control & $p m n / p m n$ & $p m n / p m n / h r l-2$ \\
\hline $\begin{array}{l}\text { Onset of clinical } \\
\text { symptoms (d) }\end{array}$ & None & $16.1 \pm 0.5(n=15)$ & $15.5 \pm 0.6(n=9)$ \\
\hline \multicolumn{4}{|l|}{ Weight of mice } \\
\hline $16 \mathrm{~d}$ & $7.6 \pm 0.8(n=9)$ & $8.5 \pm 0.3(n=8)$ & $8.3 \pm 0.4(n=7)$ \\
\hline $30 \mathrm{~d}$ & $19.3 \pm 1.8(n=9)$ & $8.2 \pm 0.7(n=8)$ & $7.9 \pm 0.5(n=7)$ \\
\hline Lifespan (d) & $\cong 2$ years & $38.2 \pm 0.6(n=13)$ & $38.0 \pm 1 \mathbf{R}_{(n=14)}$ \\
\hline $\begin{array}{l}\text { Facial motoneurons, } \\
\text { mean area }\left(\mu \mathrm{m}^{2}\right)\end{array}$ & $\begin{array}{l}285 \pm 6 \\
(n / N=4 / 284)\end{array}$ & $\begin{array}{l}227 \pm 7 * * * \\
(n / N=4 / 307)\end{array}$ & $\begin{array}{l}295 \pm 8 \\
(n / N=4 / 286)\end{array}$ \\
\hline $\begin{array}{l}\text { Optical density of } \\
\text { ChAT immunostaining }\end{array}$ & $\begin{aligned} 192 & \pm 2 \\
(n / N & =4 / 200)\end{aligned}$ & $\begin{array}{c}155 \pm 1 * * * \\
(n / N=4 / 201)\end{array}$ & $\begin{array}{l}197 \pm 2 \\
(n / N=4 / 200)\end{array}$ \\
\hline
\end{tabular}

Pmn/pmn and pmn/pmn/bcl-2 mice were identified by the atrophy of the hindlinbs and weighed at 16 and 30 d. Date of death varies from 35 to $42 \mathrm{~d}$ with an average of $38 \mathrm{~d}$. Cross-sectional area of motoneurons was measured in $30 \mu \mathrm{m}$ thick sections stained with cresyl violet, using a PC-assisted image analysis system (Software Qwin of the Leica Quantimat 500). Only cell profiles containing a distinet nucleus with nucleolus were included. Facial motoneurons in $\mathrm{pmn} / \mathrm{pmn}$ mice were significantly smaller than those of the $\mathrm{pmn} / \mathrm{pmn}$ mice overexpressing Bcl-2 or the controls $(* * *, p<0.001)$. The relative intensity of ChAT immunoreactivity was determined by obtaining the mean gray scale intensity for each outlined nucleus using a PC-assisted image analysis system (NIH IMAGE, 1.47). The background staining of adjacent ChAT negative gray matter gave a mean value of $115 \pm 2$ on a scale from 0 (white) to 250 (black). The ChAT staining intensity was significantly reduced in $\mathrm{pmn} / \mathrm{pmn}$ mice as compared to pmn/ $p m n / b c l-2$ or control animals (****, $p<0.0001$ for both). $n$, number of animals; $N$, number of cells measured.

facial motoneuron pool was counted on both sides using a Polyvar microscope at a $100 \times$ magnification. No correction for split nuclei was done. Cross-sectional area of motoneurons was measured using a PC assisted image analysis system (Software Qwin of the Leica Quantimat 500). Only cell profiles containing a distinct nucleus with nucleolus were included. Results were submitted to unpaired Student $t$ test.

Phrenic nerve. Phrenic nerves were processed as described previously (Sagot et al., 1995). Nerves were cut in cross-section at $2 \mu \mathrm{m}$ and stained with cresyl vinlet. Myelinated axons of the phrenic nerve were counted at a magnification of $630 \times$ using a Zeiss IM 35 microscope. Facial nerves were removed and processed as for the phrenic nerves. $\Lambda$ fter histological processing, nerves were photographed. Myelinated axons of the facial nerve were counted on $18 \times 24 \mathrm{~cm}$ paper print and results were submitted to unpaired Student's $t$ test.

\section{Unilateral lesion of the facial nerve}

Unilateral transection of the facial nerve of $2 \mathrm{~d}$ old mice was performed as previously described (Dubois-Dauphin et al., 1994). Three weeks after lesion, when the disease symptoms were detectable, the mice were reanesthetized, perfused and processed as described (Dubois-Dauphin et al., 1994). The entire facial motoneuron pool in serial section (30 $\mu \mathrm{m})$ was counted on both operated (exp) and the nonoperated (c) side. Results were submitted to an unpaired Student's $t$ test.

\section{Immunohistochemistry}

Bcl-2 and choline acetyltransferase (ChAT) immunoreactivity were performed on nonlesioned $38 \mathrm{~d}$ old mice according to Dubois-Dauphin et al. (1992) except that the antibody for ChAT was from BoehringerMannheim and for Bcl-2 from Dako. The relative intensity of ChAT immunoreactivity was determined by obtaining the mean gray scale intensity for each outlined nucleus using a PC-assisted image analysis system (NIH-IMAGE, 1.47). The background staining of adjacent ChAT negative gray matter gave a mean value of $115+2$ on a scale from 0 (white) to 250 (black).

\section{Results}

\section{Characterization of the new strain $\mathrm{pmn} / \mathrm{bcl} 2$}

It was important to demonstrate that the genetic background of the pmn mice did not alter the expression or function of the bcl-2 transgene. We first verified by immunostaining that pmn/ $\mathrm{pmn} / \mathrm{bcl}-2$ mice did indeed express human Bcl-2 protein. In 38 d old $\mathrm{pmn} / \mathrm{pmn}$ mice, we did not find any detectable labelling in the CNS with an antibody directed against human Bcl-2 (Fig. 1A). In contrast, in $\mathrm{pmn} / \mathrm{pmn} / \mathrm{bcl}-2$ mice there was an intense labeling in many regions of the CNS including the facial nucleus and the spinal cord motoneurons (Fig. $1 B, C$ ). No labeling was obtained when the first antibody was omitted.

Second, we confirmed that in $\mathrm{pmn} / \mathrm{pmn}$ mice, the overexpression of Bcl-2 protects motoneurons from axotomy-induced cell death as has previously been described by Dubois-Dauphin et al. (1994) using the transgenic parent strain. Three weeks after facial nerve lesion, the number of facial motoneurons was reduced by $90 \%$ in wild type mice and by $91 \%$ in $\mathrm{pmn} / \mathrm{pmn}$ mice (Fig. 2A). In animals overexpressing Bcl-2, we did not observe any motoneuron loss in either wild type or pmn homozygotes (Fig. 2A). This result confirms that the human Bcl-2 protein in the pmn strain is functional and can prevent axotomy-induced cell death.

\section{Bcl-2 does not protect against $\mathrm{pmn}$ disease}

Despite the $\mathrm{Bcl}-2$ overexpression in motoneurons of the pmn/ $p m n / b c l-2$ mice, the disease symptoms (i.e., atrophy of the hind limbs and loss of grasp activity in the back paws) appeared at the same time as in pmn homozygotes (Table 1). During the disease progression, the two groups of animals showed the same degree of muscular atrophy which was accompanied by reduced locomotor activity and inability to increase body weight (Table 1). Finally, mice of both groups died during the 6th to 7 th week of life, with an average life span of approximately $38 \mathrm{~d}$ (Table 1). Therefore Bcl-2 overexpression cannot prevent discase progression in pmn mice.

\section{Bcl-2 rescued facial motoneurons of $\mathrm{pmn} / \mathrm{pmn}$ mice}

Since Bcl-2 overexpression protected motoneurons from axotomy-induced cell death in $\mathrm{pmn} / \mathrm{pmn} / \mathrm{bcl}-2$ mice, it was of interest to determine whether $\mathrm{Bcl}-2$ was also protective against the facial motoneuron loss observed during the disease progression. Whereas 38 d old pmn homozygous mice displayed a $30 \%$ decrease of motoneurons $[2217+84(n=6)$ for $\mathrm{pm} / \mathrm{pmn}$ mice versus $3064 \pm 104(n=3)$ for control mice], this loss could be virtually prevented by the overexpression of human Bcl-2 [3153 $\pm 90(n=8)$ for $\mathrm{pmn} / \mathrm{pmn} / \mathrm{bcl}-2$ mice versus $3285 \pm 62(n=$ 4) for control mice overexpressing Bcl-2] (Figs. 2B, 4). It should 

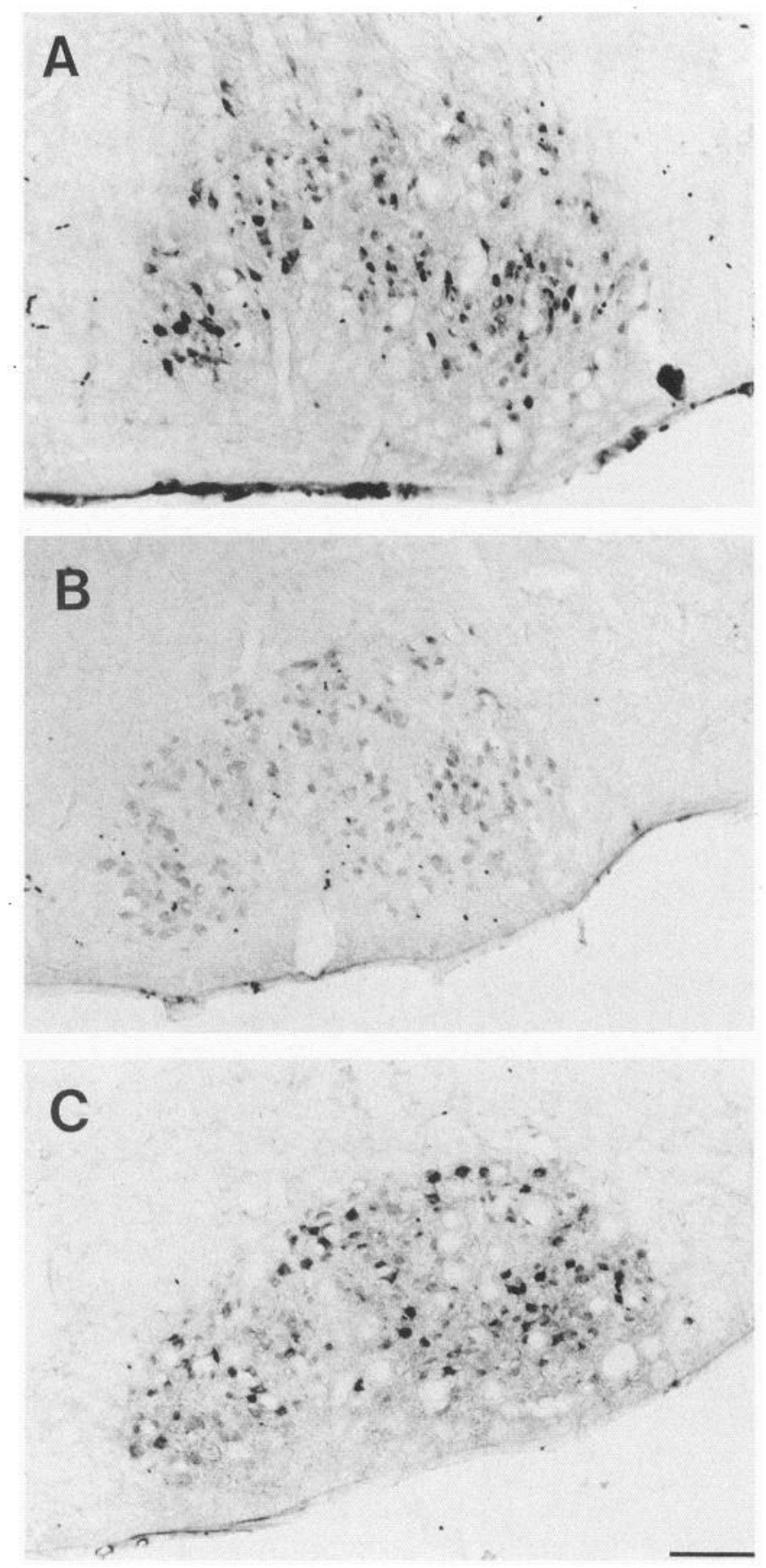

Figure 3. Comparison of ChAT immunostaining in facial motoneurons of control $(A), p m n(B)$, and pmn-Bcl-2 $(C)$ mice. In $38 \mathrm{~d}$ old pmn mice $(B)$, the staining appears weaker than in pmn-Bcl-2 $(C)$ or control (A) mice of the same age. Scale bar, $150 \mu \mathrm{m}$.

be noted that as previously reported (Dubois-Dauphin et al., 1994; Martinou et al., 1994), in the line 71 there was no significant increase in motoneuron numbers in control mice which over-express $\mathrm{Bcl}-2$ as compared to control mice.

Cell soma area and ChAT expression are considered to be characteristic of motoneuron integrity. These two morphological features were preserved in $\mathrm{pmn} / \mathrm{pmn} / \mathrm{bcl}-2$ mice whereas they were significantly diminished in the original $\mathrm{pmn} / \mathrm{pmn}$ strain at $38 \mathrm{~d}$ of age (Table 1, Fig. 3). In $\mathrm{pmn} / \mathrm{pmn}$ mice facial motoneu- rons were significantly smaller than the wild type and there was an additional population of small cells $(9.2 \%$ of the total population versus $0.35 \%$ for $\mathrm{pmn} / \mathrm{pmn} / \mathrm{bcl}-2$ or control mice) that had a surface area of less than $100 \mathrm{\mu m}^{2}$. In contrast, in pmn/ $\mathrm{pmn} / \mathrm{bcl}-2$ mice, there was no significant change in the cell surface as compared to wild type.

\section{Bcl-2 does not prevent nerve degeneration of $\mathrm{pmn} / \mathrm{pmn}$ mice}

Although $\mathrm{Bcl} 2$ was able to rescue motoneurons in $\mathrm{pmn} / \mathrm{pmn} /$ $b c l-2$ animals, it did not improve their locomotor activity or lifespan. We therefore decided to analyze the histological integrity of two motor nerves, the phrenic and the facial. Counts of myelinated fibers in both nerves revealed that in $38 \mathrm{~d}$ old $\mathrm{pmn} /$ $\mathrm{pmn} / \mathrm{bcl}-2$ mice, there was a loss of myelinated axon profiles which was comparable to that observed in pmn homozygotes of the same age (Fig. 5A,B). In control animals, the ratio of facial motoneuron cell body counts to the axons counts of the facial nerve (1.16 for control mice, 1.22 for control mice overexpressing Bcl-2) compared well to the results previously published by Martinou et al. (1994). Interestingly, this ratio is higher in pmn/ $\mathrm{pmn} / \mathrm{bcl}-2$ mice (1.48), indicating that the cell bodies were preserved while axon numbers were reduced. As compared to control animals, phrenic and facial nerves of $\mathrm{pmn} / \mathrm{pmn}$ and $\mathrm{pmn} /$ $\mathrm{pmn} / \mathrm{bcl}-2$ mice displayed pathological features including the absence of a compact fiber structure (Fig. 4).

\section{Discussion}

Bcl-2 can prevent motoneuron cell death but does not affect the life span of pmn mice

In the present study, we have used a mouse mutant with a genetic neuromuscular dysfunction to determine whether the protein $\mathrm{Bcl}-2$ could prevent the disease progression in an animal model which may reflect a human motor neuron disease. Using immunostaining, we have shown that the human Bcl-2 oncoprotein is over-expressed in many neuronal populations including motoneurons, which are those that are affected in the pmn mutation. In addition, we verified that the biological activity of the human $\mathrm{Bcl}-2$ protein was not altered as shown by rescue of the facial motoneurons following nerve lesion in the $\mathrm{pmn} / \mathrm{pmn} / \mathrm{bcl}-2$ neonate. Therefore the genetic background of $\mathrm{pmn} / \mathrm{pmn}$ mice did not alter the expression or function of the $\mathrm{Bcl}-2$ protein.

We have demonstrated that $\mathrm{Bcl}-2$ protects motoneurons from cell death that normally occurs during progression of the "pmn" disease and it also preserves their cell soma area and ChAT expression. Since in the line 71 , control mice overexpressing Bcl-2 did not have more motoneurons than nontransgenic animals (Dubois-Dauphin et al., 1994; Martinou et al., 1994), we assumed that the effect of $\mathrm{Bcl}-2$ is due to a genuine protective effect on motoneuron survival. However, despite these positive effects of $\mathrm{Bcl}-2$, the overexpression of the proto-oncogene cannot prevent the degeneration of myelinated motor fibers. The phrenic nerve degeneration as well as the muscle wasting observed in $\mathrm{pmn} / \mathrm{pmn} / \mathrm{bcl}-2$ and $\mathrm{pmn} / \mathrm{pmn}$ mice may explain their premature death.

The "pmn" disease has been described as a "dying back" motoneuronopathy affecting initially the axons and thereafter the cell bodies (Schmalbruch et al., 1991; Sendtner et al., 1992). Furthermore, electrophysiological studies (P. Kennel, personal communication) and histological analyses (Schmalbruch et al., 1991) support the hypothesis that this disease is not due to a defect in peripheral nerve fiber myelination. Since we observed that the rescue of the motoneuron cell body cannot alter the 

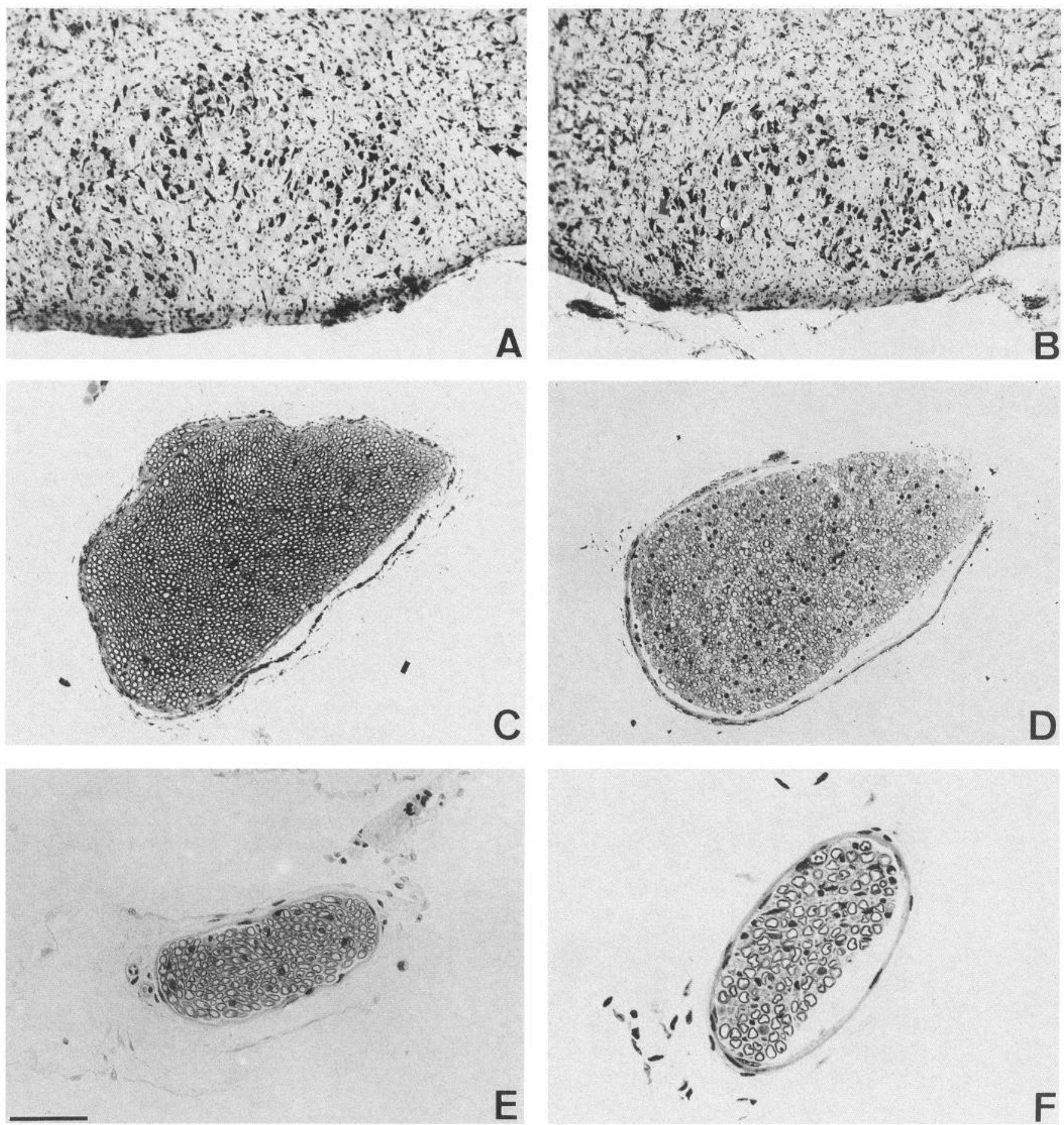

Figure 4. Micrographs of cross-sections of facial nucleus $(A, B)$; facial nerves $(C, D)$ and phrenic nerve $(E, F)$ from $38 \mathrm{~d}$ old mice. $A, C$, and $E$ from a control littermate overexpressing Bcl-2; $B, D$, and $F$ from a $\mathrm{pmn} / \mathrm{pmn} / \mathrm{bcl}-2$ mice. Note the pathological features in nerves from $\mathrm{pmn} / \mathrm{pmn} /$ bcl-2 mice. Scale bar: $A$ and $B, 200 \mu \mathrm{m} ; C$ and $D, 50 \mu \mathrm{m} ; E$ and $F, 75 \mu \mathrm{m}$.

disease progression, we suggest that the etiology of the "pmn" disease is not due to a primary disruption of the soma integrity.

In $p m n / p m n$ mice, the protective effects of Bcl-2 appear to be limited to the neuronal cell body rather than the axon. Since the $\mathrm{pmn} / \mathrm{pmn} / \mathrm{bcl}-2$ mice developed the disease at the same time as pmn/pmn animals, it would appear that $\mathrm{Bcl}-2$ is also unable to slow down the degenerative process of the disease. These findings contrast to those obtained when ciliary neurotrophic factor
(CNTF) was used as a therapeutic agent in pmn/pmn mice. When CNTF was delivered, using either intraperitoneal implantation of a cell line (Sendtner et al., 1992) or via an engineered cell encapsulation technique (Sagot et al., 1995), a significant increase in the life span was observed. Furthermore, there was a rescue of facial motoneurons ( $86.4 \%$ of the normal value) and a $42 \%$ reduction in the loss of myelinated fibers of the phrenic nerve (Sendtner et al., 1992; Sagot et al., 1995). Therefore, pres- 
a

\section{Phrenic Nerve}

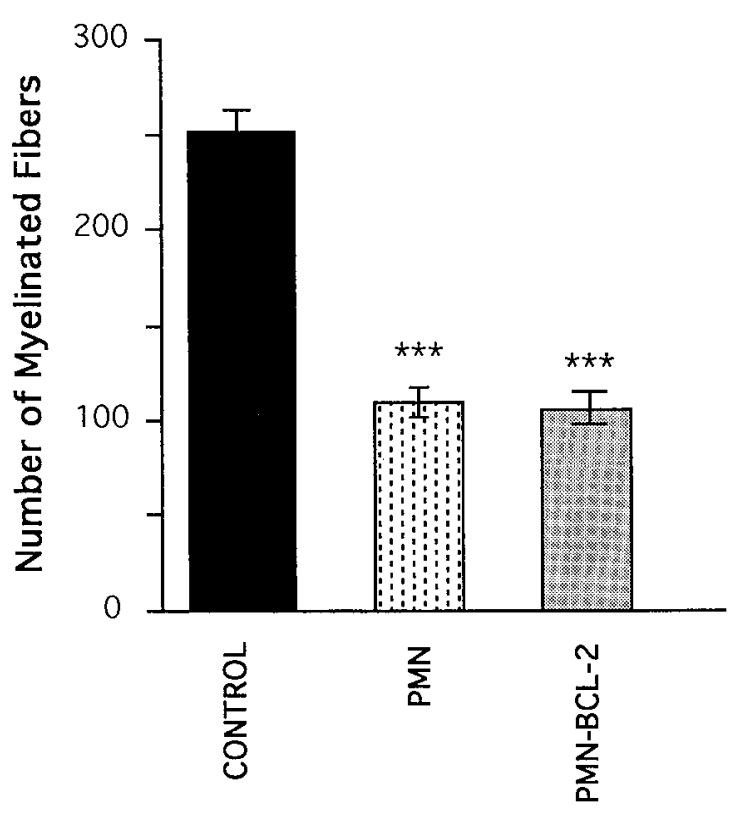

$b$

Facial Nerve

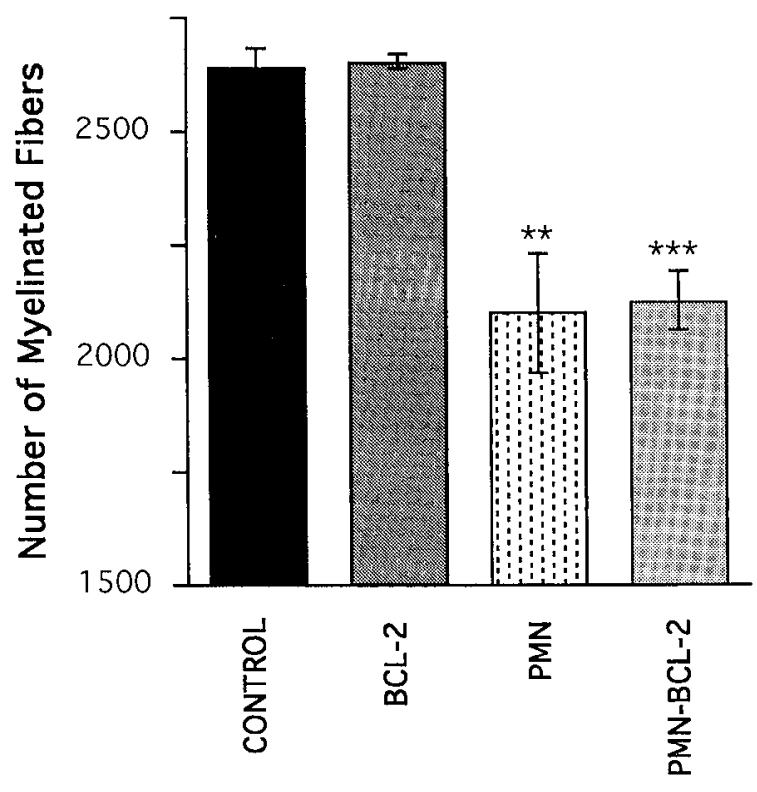

Figure 5. Histogram showing the number of myelinated axons $( \pm$ SEM) in a cross-section of the phrenic $(A)$ and the facial nerves $(B)$. $A$, In $p m n / p m n ~(n=4)$ and $p m n / p m n / b c l-2(n=7)$ mice, the number of myelinated axons is significantly reduced $\left({ }^{* * *}, p<0.001\right)$ as compared to control mice $(n=6)$. $B$, No difference was observed in control mice $(n=3)$ or $\mathrm{Bcl}-2$ control mice $(n=3)$. In contrast, $p m n / p m n(n$ $=3$ ) and $p m n / p m n / b c l-2$ mice $(n-5)$ displayed a reduced number of myelinated fibers as compared to controls $\left({ }^{*}, p<0.01\right.$; ***, $p<$ 0.001 ). The number of myelinated axons of pmn/pmn/bcl-2 mice was not statistically different from the $\mathrm{pmn} / \mathrm{pmn}$ animals. ervation of myelinated motor fibers is possible in pmn animals but it appears to be refractory to the action of $\mathrm{Bcl}-2$.

CNTF appears to play a more pleiotropic role as compared to Bcl-2 probably due to its effects on motor nerve terminal sprouting (Kwon and Gurney, 1994), potentiation of nerve regeneration (Sahenk et al., 1994) and also its direct effect on muscle (Helgren et al., 1994). Allsopp et al. (1995) have recently shown that the effects of CNTF on sensory and parasympathetic neurons are not hediated by Bcl-2. Our observations would also suggest that in $p m n / p m n$ mice, CNTF and $\mathrm{Bcl}-2$ act on distinct regulatory pathways-effects of $\mathrm{CNTF}$ involve both survival and neurite outgrowth whereas $\mathrm{Bcl}-2$ has a unique action on neuronal cell body survival.

\section{Dichotomy between motoneuron survival and nerve degeneration}

These in vivo results appear to reflect the observations made by others using in vitro techniques. For example, it has been shown that $\mathrm{Bcl}-2$ overexpression in PC12 cells can prevent apoptosis without inducing neuronal differentiation or interfering with the ability of NGF to promote neurite outgrowth (Batistatou et al., 1993). Also cultured sensory (Gagliardini et al., 1994) and sympathetic ganglion (Garcia et al., 1992) neurons that have been microinjected with a $\mathrm{Bcl}-2$ expression vector, were shown to survive in the absence of NGF but the cells remained round and often devoid of extensive neurites.

This dichotomy between neuronal survival and neurite outgrowth, has already been reported by others using various other agents in vitro. Greene et al. (1990) showed that certain purine analogs could inhibit NGF-promoted neurite outgrowth in cultured sympathetic and sensory neurons without affecting survival. In chick nodose ganglion cultures, a chimeric neurotrophic protein was shown to induce neurite outgrowth but not neuronal survival (Ibanez et al., 1993). Also a specific inhibitor of apoptosis (crmA), which acts on an interleukin-1 $\beta$-converting enzyme, has been shown to prevent neuronal cell death without inducing fiber outgrowth (Gagliardini et al., 1994). Furthermore, in a mouse model of slow Wallerian degeneration, it has been shown in vitro that the mechanisms underlying neurite and soma degeneration are autonomous and independent from each other (Deckwerth and Johnson, 1994). Our data are the first demontration that such a dichotomy indeed exists in vivo.

\section{Inadequacy of $\mathrm{Bcl}-2$ for treatment of neurodegenerative diseases}

These findings demonstrate both the interest and limitations of $\mathrm{Bcl}-2$ with respect to a therapeutic approach for neurodegenerative diseases. Whereas $\mathrm{Bcl}-2$ may be an efficient molecule for treating diseases associated with cell body dysfunction, it appears to be a poor candidate for the treatment of diseases characterized by axonal impairment. Recent reports have suggested that amyotrophic lateral sclerosis could be due to an impairment of anterograde axonal transport (Collard et al., 1995). If so, Bcl-2 would probably be unable to act therapeutically on such a disease. However, by arresting the cell death progression, $\mathrm{Bcl}-2$ could mitigate the degeneration of the cell soma and allow cotreatment with a other therapeutic agents which would act on axonal maintenance.

\section{References}

Allsopp TE, Wyatt S, Paterson HF, Davies AM (1993) The proto-oncogene $b c l-2$ can selectively rescue neurotrophic factor-dependent neurons from apoptosis. Cell 73:295-307. 
Allsopp TE, Kiselev S, Wyatt S, Davies AM (1995) Role of Bcl-2 in the brain-derived neurotrophic factor survival response. Eur J Neurosci 7:1266-1272.

Batistatou A, Merry DE, Korsmeyer SJ, Greene LA (1993) Bcl-2 affects survival but not neuronal differentiation of PC12 cells. J Neurosci 13:4422-4428.

Collard J-F, Côté F, Julien J-P (1995) Defective axonal transport in a transgenic mouse model of amyotrophic lateral sclerosis. Nature 375: $61-64$.

Deckwerth TL, Johnson EM Jr (1994) Neurites can remain viable after destruction of the neuronal soma by programmed cell death (apoptosis). Dev Biol 165:63-72.

Dubois-Dauphin M, Raggenbass M, Widmer H, Tribollet E, Dreifuss JJ (1992) Morphological and electrophysiological evidence for postsynaptic localization of functional oxytocin receptors in the rat dorsal motor nucleus of the vagus nerve. Brain Res 575:124-131.

Dubois-Dauphin M, Frankowski H, Tsujimoto Y, Huarte J, Martinou J-C (1994) Neonatal motoneurons overexpressing the $b c l-2$ protooncogene in transgenic mice are protected from axotomy-induced cell death. Proc Natl Acad Sci USA 91:3309-3313.

Ellis RE, Yuan J, Horvitz HR (1991) Mechanisms and functions of cell death. Annu Rev Cell Biol 7:663-698.

Gagliardini V, Fernandez P-A, Lee RKK, Dreyler HCA, Rotello RJ, Fishman MC, Yuan J (1994) Prevention of vertebrate neuronal death by the $\mathrm{crmA}$ gene. Science 263:826-828.

Garcia I, Martinou I, Tsujimoto Y, Martinou J-C (1992) Prevention of programmed cell death of sympathetic neurons by the $b c l-2$ protooncogene. Science 258:302-304.

Greene LA, Volonté C, Chalazonitis A (1990) Purine analogs inhibit nerve growth factor-promoted neurite outgrowth by sympathetic and sensory neurons. J Neurosci 10:1479-1485.
Helgren ME, Squinto SP, Davis HL, Parry DJ, Boulton TG, Heck CS, Zhu Y, Yancopoulos GD, Lindsay RM, DiStefano PS (1994) Trophic effect of ciliary neurotrophic factor on denervated skeletal muscle. Cell 76:493-504.

Ibanez CF, Ilag LL, Murray-Rust J, Persson H (1993) An extended surface of binding to Trk tyrosine kinase receptors in NGF and BDNF allows the engineering of a multifunctional pan-neurotrophin. EMBO J 12:2281-2293.

Kwon YW, Gurney MF (1994) Systemic injections of ciliary neurntrophic factor induce sprouting by adult motor neurons. Neuroreport 5:789-792.

Martinou J-C, Dubois-Dauphin M, Staple JK, Rodriguez I, Frankowski H, Missotten M, Albertini P, Talabot D, Catsicas S, Pietra C, Huarte $\mathrm{J}$ (1994) Overexpression of BCL-2 in transgenic mice protects neurons from naturally occurring cell death and experimental ischemia. Neuron 13:1-20.

Sagot Y, Tan SA, Baetge E, Schmalbruch H, Kato AC, Aebischer P (1995) Polymer encapsulated cell lines genetically engineered to release ciliary neurotrophic factor can slow down progressive motor neuronopathy in the mouse. Eur J Neurosci 7:1313-1322.

Sahenk Z, Seharaseyon J, Mendell JR (1994) CNTF potentiates peripheral nerve regeneration. Brain Res 655:246-250.

Schmalbruch $H$, Iensen H-IS, Bjaerg M, Kamieniecka 7, Kurland L (1991) A new mouse mutant with progressive motor neuronopathy. J Neuropathol Exp Neurol 50:192-204.

Sendtner M, Schmalbruch H, Stöckli K $\Lambda$, Carroll P, Kreutzberg GW, Thoenen H (1992) Ciliary neurotrophic factor prevents degeneration of motor neurons in mouse mutant progressive motor neuronopathy. Nature 358:502-504

Thompson CB (1995) Apoptosis in the pathogenesis and treatment of disease. Science 267:1456-1462. 